Febby Febrian, Rahmadani Yusran| Koordinasi dalam Implementasi Kebijakan Pencegahan Stunting di Kota Padang

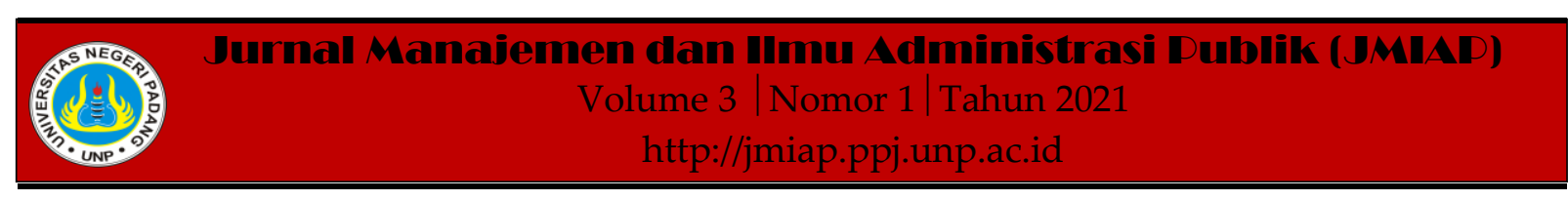

\title{
KOORDINASI DALAM IMPLEMENTASI KEBIJAKAN PENCEGAHAN STUNTING DI KOTA PADANG
}

\author{
Febby Febrian $^{1(a)}$, Rahmadani Yusran ${ }^{2(b)}$ \\ ${ }^{1}$ Jurusan Ilmu Administrasi Negara, Universitas Negeri Padang \\ ${ }^{2}$ Jurusan Ilmu Administrasi Negara, Universitas Negeri Padang \\ a)febbyfebrian1827@gmail.com, ${ }^{b)}$ yusranrdy@fis.unp.ac.id
}

ABSTRACT - The study to analyze coordination about stunting prevention policies in Padang. The
mechanisms coordination about stunting prevention policies at Padang. And factors inhibiting of
stunting prevention coordination in the City of Padang. The research is a qualitative with descriptive
analyze. The research was related agencies at Padang that are relevant to the implementation of
stunting prevention policy coordination at Padang. This related agency are also the research informant.
Got that information that the coordination of stunting prevention policy at Padang was only running at
the sectoral level. The Health Office and its staff and have not coordinated cross-sectoral with other
agencies that specifically discuss stunting prevention. The coordination mechanism in the
implementation of stunting prevention policies at Padang has only been implemented in the ranks of the
Health Office and its staff in the form of mini workshops involving the puskesmas team, sub-district
officials and village staff through the nutrition program. The inhibiting factor in the implementation of
coordination of stunting prevention policies at Padang was that absence regulations affects the clarity
of the main functions and duties of the institutions involved, the absence of a special budget on stunting
prevention. It's caused to the perceived low incidence of stunting at Padang City and Padang City which
are not included in the stunting locus area.
Keywords : Policy, Coordination, Implementation, Stunting
Corresponding author. Email. febbyfebrian1827@gmail.com
How to cite this article. Febrian, F \& Yusran, R. (2021). Koordinasi dalam Implementasi Kebijakan
Pencegahan Stunting di Kota Padang. Jurnal Manajemen dan Ilmu Administrasi Publik (JMIAP) Jurusan
Ilmu Administrasi Negara Fakultas Ilmu Sosial Universitas Negeri Padang, Volume 3 (1), Hal. 11-21.
http://jmiap.ppj.unp.ac.id
Copyright@2021. Published by Labor Jurusan Ilmu Administrasi Negara FIS UNP, Padang 


\section{PENDAHULUAN}

Kebijakan pencegahan stunting di Indonesia, erat kaitannya dengan kebijakan perbaikan gizi. Karena stunting menurut Kementerian Kesehatan Republik Indonesia merupakan dampak dari kekurangan gizi kronis pada balita sehingga menjadi lebih pendek pada usianya. Hal ini terjadi dimulai pada awal pembentukkan janin sampai anak berusia dua tahun, (Doddy, 2019:20).

Kebijakan pencegahan stunting di Indonesia telah diatur dalam beberapa bentuk peraturan, yaitu seperti UU No. 36 tahun 2009 tentang Kesehatan yang terdapat pada pasal 141, 142, dan 143. Didalam undang-undang ini dijelaskan bahwa perbaikan gizi diarahkan kepada upaya memperbaiki pola konsumsi makanan yang sesuai dengan gizi seimbang, meningkatkan kesadaran prilaku gizi, melakukan aktivitas fisik dan kesehatan, meningkatkan ketercapaian sarana dan mutu pelayanan gizi, peningkatan sistem kewaspadaan pangan dan gizi serta upaya meningkatkan kerja sama pemerintah dan masyarakat dalam menjamin ketersediaan bahan makanan.

Perpres No. 42 Tahun 2013 tentang Gerakan Nasional Percepatan Perbaikan Gizi (Gernas PPG) juga mengatur tentang upaya dalam pencegahan stunting merupakan upaya pencegahan secara bersama. Pada pasal 1 ayat (1) disebutkan bahwa upaya percepatan perbaikan gizi dilakukan secara bersama antara pemerintah dan masyarakat melalui penggalangan partisipasi dan kepedulian pemangku kepentingan secara terencana dan terkoordinasi untuk percepatan perbaikan gizi. Dari undang-undang dan peraturan presiden yang telah dijelaskan diatas terlihat bahwa adanya penekanan dalam upaya pelaksanaan pencegahan stunting di Indonesia, namun dalam penerapannya masih belum optimal dilaksanakan. Sehingga berdampak kepada angka prevalensi stunting di Indonesia yang fluktuatif dari tahun ke tahunnya.
Untuk memperkuat pedoman pencegahan stunting di Indonesia, maka pemerintah menetapkan dokumen Strategi Nasional Percepatan Stunting (Stranas Stunting) tahun 2018. Salah satu tujuan dokumen Strategi Nasional Percepatan Stuntingini adalah diaturnya tentang perlibatan multi sektoral sebagai salah satu upaya percepatan penurunan stunting (Kementerian Keuangan dan Kementerian PPN, 2019:1). Karena selama ini salah satu penyebab terhambatnya pelaksanaan pencegahan stunting di Indonesia adalah belum optimalnya koordinasi antar lembaga pemerintah (TNP2K, 2018:5).

Koordinasi antar lembaga pemerintah merupakan cara yang strategis dalam mencapai tujuan yang diinginkan, mengingat kejadian stunting disebabkan oleh berbagai aspek. Adapun keterlibatan multi sektoral tersebut terdiri dari sektor kesehatan, ketersediaan pangan, pendidikan, air bersih dan sanitasi, serta jaminan sosial (Kementerian Keuangan, dan Kementerian PPN, 2019:1).

Prevalensi stunting di Kota Padang pada tahun 2017 cukup tinggi yaitu mencapai angka 20,04 \% (Harian Haluan, 23 November 2018). Tahun 2018 terjadi penurunan cukup jauh menjadi 7,65\% atau 3.943 (Profil Kesehatan Kota Padang, 2018). Tahun 2019 naik kembali menjadi 9.6\% atau 4.266 (Profil Kesehatan Kota Padang, 2019). Kondisi ini menjadi persoalan yang harus segera diselesaikan.

Dalam pelaksanaan pencegahan stunting di Kota Padang belum optimal dilakukan. Hal ini disebabkan karena berbagai permasalahan, yaitu belum optimalnya koordinasi pemangku kepentingan pada intervensi gizi spesifik dan sensitif. Kedua, sosialisasi belum optimal dilakukan karena masih terbatasnya sosialisasi tentang gizi. Ketiga karena tumpang tindih terhadap program prioritas yang dilaksanakan. Akibatnya pencegahan stunting juga tidak dapat menjadi suatu permasalahan yang serius bagi lembaga lain sebagai lembaga yang terkoordinasikan untuk mempercepat penanggulangan stunting. 
Keempat, koordinasi antar lintas sektor organisasi pemerintah belum didukung dengan regulasi khusus daerah. Kelima, masih adanya tenaga kesahatan/tenaga edukasi yang memberikan pelayanan langsung kepada masyarakat belum memiliki pemahaman yang cukup tentang gizi yang baik.

Berdasarkan permasalahan pencegahan stunting di atas peneliti melakukan penelitian tentang "Koordinasi Dalam Implementasi Kebijakan Pencegahan Stunting di Kota Padang “.

\section{TINJAUAN PUSTAKA}

\section{Konsep Kebijakan Publik}

Konsep kebijakan publik dikemukakan oleh Lasswel dan Kaplan (1970) dalam Islamy (2009:15) yang mengemukakan bahwa kebijakan publik sebagai suatu program pencapaian tujuan, nilai-nilai dan praktek-praktek yang terarah. Pernyataan Lasswel dan Kaplan ini diperkuat oleh pendapat Raksasataya yang menyatakan bahwa kebijakan publik merupakan langkah - langkah strategi dalam mencapai suatu tujuan (Islamy, 2009:17). Sejalan dengan pendapat Lasswel dan Kaplan dan Raksasataya, Aminullah yang dikutip oleh Taufiqurokhman (2014:07) dalam Muhammadi (2001) bahwa kebijakan merupakan upaya strategis yang dilakukan untuk mencapai tujuan yang diinginkan, bersifat jangka panjang dan menyeluruh.

\section{Konsep Implementasi Kebijakan}

Menurut Van meter dan Van Horn dalam Aprina dan Yusran (2019) menyatakan implementasi kebijakan sebagai langkah langkah yang dilakukan oleh pemerintah dan swasta secara perorangan ataupun berkelompok dalam mencapai suatu tujuan. Pendapat lain disampaikan oleh Mulyadi (2016:12), bahwa implementasi merupakan tindakan untuk mencapai tujuan sesuai dengan ketetapan pada sebuah keputusan. Tindakan tersebut mengarah pada upaya untuk merubah sebuah keputusan menjadi pola operasional untuk mencapai suatu perubahan sesuai dengan keputusan yang telah ditetapkan.

\section{Konsep Koordinasi Kebijakan}

Menurut James Af Stoner dalam Purwanto dan Sulistyastuti (2012:153), koordinasi sebagai suatu kegiatan untuk mencapai sasaran dan kegiatan dari unit kerja yang terpisah dalam tujuan organisasi secara efektif. Pendapat ini didukung oleh pendapat Koontz dan O'Donell yang dikutip oleh Akmal (2006:4) dalam Irmadi (1991) yang menyatakan bahwa koordinasi ialah upaya yang dilakukan untuk memadukan proses pada beberapa satuan unit kegiatan pada organisasi dalam mencapai tujuan organisasi tersebut.

Konsep koordinasi juga dijelaskan oleh G.R Terry dalam Hasibuan (2014:85) yang menyatakan bahwa koordinasi sebagai kegiatan yang terarah dalam mengatur jumlah dan waktu yang tepat pada pelaksanaan suatu kegiatan agar sesuai dengan sasaran yang telah ditentukan. Pendapat G.R Terry didukung oleh Ndraha (2003:291) yang menyatakan bahwa koordinasi sebagai upaya mencapai proses kesepakatan secara bersama dan mengikat pada kegiatan atau unsur yang berbeda sehingga menjadi satu kesatuan kegiatan yang terarah untuk target keberhasilan organisasi.

\section{Konsep Stunting}

Stunting merupakan salah satu dari sekian banyak permasalahan gizi yang menjadi perhatian dunia. Stunting juga merupakan bagian dari tujuan yang ingin dicapai dalam Sustainable Developmment Goal (SDGs) sebagai wujud dari pembangunan berkelanjutan. Stunting termasuk kedalam bagian pembangunan berkelanjutan yaitu untuk menghilangkan segala bentuk malnutrisi atau kelaparan salah satunya dengan meningkatkan ketahanan pangan (Rini dan Jeki, 2019. Besarnya perhatian dunia terhadap upaya pencegahan stunting menyangkut kepada kualitas sumber daya manusia dimasa depan. 
Febby Febrian, Rahmadani Yusran I Koordinasi dalam Implementasi Kebijakan Pencegahan Stunting di Kota Padang

Stunting adalah gangguan pertumbuhan dan perkembangan pada balita akibat gizi buruk dan kondisi sosial yang tidak memadai, balita dikatakan stunting jika tinggi badan berdasarkan umur lebih dari dua Standar Deviasi (SD) (WHO). Sedangakan menurut TNP2K (2017:5) stunting didefinisikan sebagai gagal tumbuh pada balita akibat gizi kronis, yang tinggi badan balita tidaklah sesuai dengan usianya. Sementara itu stunting menurut Kepmenkes RI No. 1995/MENKES/SK/XII/2020 tentang Standar Antropometri Penilaian Status Gizi Anak mendefinisikan sebagai status gizi yang didasarkan pada indeks Panjang Badan berdasarkan Umur (PB/U) atau Tinggi Badan berdasarkan Umur (TB/U) dengan nilai kurang dari -2 SD (pendek) dan kurang di -3 SD (sangat pendek).

Stunting tidak hanya berdampak pada gagal tumbuh anak, tetapi juga dapat berdampak pada intelektual anak bahkan penyakit kronis laiinya seperti kanker yang dapat mengganggu pendapatan perkapita Indonesia dimasa yang akan datang (Kementerian PPN/Bappenas, 2018:04).

\section{METODE PENELITIAN}

Penelitian dengan jenis kualitatif deskriptif. Penelitian dilakukan pada Dinas - Dinas terkait yang ada di Kota Padang yang relevan terhadap pelaksanaan koordinasi kebijakan pencegahan stunting di Kota Padang. Dinas yang terkait ini sekaligus menjadi informan penelitian yaitu Badan Perencanaan Pembangunan Daerah Kota Padang (BAPEDA), Dinas Kesehatan, Dinas Perumahan Rakyat Kawasan Permungkiman dan Pertanahan (DPRKPP), Dinas Pangan, Dinas Sosial, Dinas Komunikasi dan Informasi, Dinas Pemberdayaan Perempuan Perlindungan Anak Pengendalian Penduduk dan Keluarga Berencana (DP3AP2KB), Staf di Kecamatan yang terkait, Kelurahan Kota Padang (terkait), Puskemas Kota Padang (terkait). Teknik analisis data berdasarkan teori Sugiyono (2012:247-252) berupa meliputi reduksi, penyajian data dan verifikasi.

HASIL DAN PEMBAHASAN

\section{Pelaksanaan Koordinasi Kebijakan Pencegahan Stunting di Kota Padang}

Pelaksanaan kebijakan pencegahan stunting adalah suatu kegiatan untuk memperbaiki pola gizi di masyarakat yang memiliki pengaruh terhadap kejadian stunting terutama sejak awal pembentukkan janin sampai kelahiran bayi dan sampai bayi berusia dua tahun. Dua tahuh kehidupan adalah periode emas bagi kehidupan anak. Pada fase ini kecukupan gizi sangat perlu diperhatikan untuk pertumbuhan bayi sehingga dapat mencegah stunting. Pemantauan asupan gizi ibu hamil perlu dilakukan sampai ibu melahirkan begitu juga selama ibu menyusui dan bayi yang disusui. Tidak hanya itu, kondisi lingkungan selama fase seribu hari pertama kehidupan juga tidak kalah penting untuk diperhatikan baik instansi yang bersangkutan maupun lembaga yang terlibat.

Pelaksanaan pencegahan stunting, tidak hanya menjadi kewajiban dari instansi Dinas Kesehatan saja, akan tetapi melibatkan peran serta dari lembaga lain yang memiliki pengaruh terhadap kejadian stunting. Dalam hal ini, koordinasi perlu di bangun untuk dapat menyatukan sasaran dan kegiatan dari unit organisasi yang terlibat secara peraturan. Peraturan ini dimuat dalam pasal 1 ayat (1) Peraturan Presiden No.42 Tahun 2013 tentang Gerakan Nasional Percepatan Perbaikan Gizi yang menyatakan bahwa percepatan perbaikan gizi secara nasional merupakan upaya bersama antara pemerintah dan masyarakat melalui penggalangan partisipasi dan kepedulian pemangku kepentingan secara terencana dan terkoordinasi. Kebijakan ini bertujuan untuk meningkatkan peran stakeholder dalam pemenuhan gizi masyarakat, meningkatkan pengelolaan program gizi yang lebih baik, dan adanya koordinasi antar sektor dalam upaya perbaikan gizi, 
serta memperkuat pelaksanaan konsep program gizi yang bersifat langsung dan tidak langsung.

Berdasarkan temuan dilapangan koordinasi dalam rangka pencegahan stunting diantara pemangku kepentingan di Kota Padang belum terlaksana sebagaimana mestinya sesuai dengan Perpres No 42 Tahun 2013. Pelaksanaan koordinasi tidak dilakukan secara spesifik pada upaya pencegahan stunting, baik secara sektoral maupun lintas sektoral. Koordinasi dilakukan secara terbatas sesuai kebutuhan saja, dan belum dilakukan secara kontinue dalam jangka panjang.

Koordinasi sektoral pencegahan stunting itu dilakukan antara dinas kesehatan beserta jajaran dibawahnya yaitu melalui indikator program gizi yang dilaksanakan tiap tahunnya dari kementerian kesehatan. Sementara program khusus pada pencegahan stunting selama ini belum dilakukan. Adapun program khusus stunting yang dimiliki oleh puskesmasnya merupakan inisiatif dari puskesmas itu sendiri. Stunting hanya dibahas secara umum seperti verifikasi data angka stunting ditiap puskesmas Kota Padang. Karena stunting merupakan salah satu bagian dari banyaknya permasalah gizi pada ibu hamil dan anak balita seperti gizi buruk, kurus, dan underweight. Dengan berjalan baiknya seluruh program gizi yang telah dimiliki selama ini, pihak kesehatan Kota Padang meyakini bahwa angka stunting ini bisa ditekan dengan sendirinya. Karena tidak hanya stunting, permasalah gizi lainnya pun ikut teratasi. Itu lah sebab nya koordinasinya ini dapat dikatakan masih bersifat umum.

Hal yang sama juga terjadi terhadap program lembaga lainnya yang dapat membantu pencegahan stunting yang masih berjalan dengan sendirinya, sesuai dengan tupoksi yang mereka miliki. Hal ini dibuktikan dari hasil temuan penelitian terhadap Organisasi Perangkat Daerah diluar Kesehatan dan pengakuan langsung dari pihak kesehatan sendiri. Mereka yang seharusnya terlibat tidak merasa memiliki bahwa pencegahan stunting ini dapat dibantu langsung oleh program yang mereka miliki sesuai dokumen pencegahan stunting yang telah ada. Sehingga, adanya koordinasi lintas sektoral yang terjadi antara pihak kesehatan dengan lembaga yang terkait itu juga hanyalah bersifat umum. Artinya koordinasi lintas sektoral terjadi ketika ada keterkaitan data dinas lain di kesehatan itu sendiri. Yang pada dasarnya mereka tidak mengetahui secara langsung apakah koordinasi yang dilakukan itu salah satunya bertujuan untuk membantu pencegahan stunting atau tidak. Yang mereka ketahui hanyalah koordinasi yang ada itu dilakukan karena ada saling keterbutuhan data antara dinas yang satu dengan dinas yang lain. Koordinasi yang terjadi antara lintas sektor juga bersifat sementara, dan tidaklah bersifat continue.

Hal ini disebabkan karena masih rendahnya angka kejadian stunting di Kota Padang, sehingga belum menjadi masalah yang besar di tingkat Kota Padang. Angka prevalensi stunting di Kota Padang itu di tahun 2019 hanyalah $9,6 \%$ atau 4.266 balita di Kota Padang terdampak sunting dibawah target RPJMN yaitu 28\%. Rendahnya kejadian angka stunting menimbulkan pandangan dari pihak kesehatan maupun lembaga lain sesuai dengan temuan penelitian yang menganggap bahwa Kota Padang belum perlu di jadikan lokus stunting yang juga akan mempengaruhi kebijakan dari daerah Kota Padang itu sendiri untuk pencegahan Stunting. Namun pada kenyataannya sesuai dengan temuan penelitian bahwa Kota padang akan lokus stunting di tahun 2021 karena di tahun 2020 angka prevalensi stunting Kota Padang dinilai tinggi dari pemerintah pusat.

Kondisi ini lah yang mempengaruhi mind set di kalangan OPD selama ini bahwa masalah stunting merupakan masalah urusan Dinas Kesehatan saja. Umumnya, mereka (lembaga yang seharusnya terlibat) beranggapan bahwa kebijakan pencegahan stunting tidak berkaitan dengan urusan dan kewenangan OPDnya. Dalam hal ini, instansi yang sering menjadi perhatian 
pencegahan stunting hanyalah Dinas Kesehatan melalui kasi kesehatan keluarga dan yang membawahinya tim puskesmas yaitu melalui program gizi.

Sementara itu, Presiden Republik Indonesia Joko Widodo baru-baru ini menunjuk Badan Kependudukan dan Keluarga Berencana Nasional (BKKBN) sebagai leading sektor pelaksanaan pencegahan stunting di Indonesia. Hal ini dilakukannya dengan pertimbangan kemampuan "dobrak" BKKBN di lapangan dengan tim yang cukup besar yaitu sekitar 14 ribu Petugas Penyuluh Lapangan Keluarga Berencana (PLKB/PKB) dari unsur ASN (Aparatur Sipil Negara) dan anak 10 ribu petugas non-ASN (Republika, 2020).

Berdasarkan temuan di lapangan pelaksanaan koordinasi lintas sektoral kebijakan pencegahan stunting yang telah dijelaskan sebelumnya belum dilaksanakan sesuai dengan aturan yang berlaku. Koordinasi lintas sektoral hanya dilakukan untuk menyamakan persepsi tentang realisasi program di lapangan seperti koordinasi dengan dinas informatika tentang penyebaran informasi terkait dengan program Dinas Kesehatan. Koordinasi dengan Dinas Pemberdayaan Perempuan Perlindungan Anak Pengendalian Penduduk dan Keluarga Berencanan (DP3AP2KB), terkait dengan penguatan kader yang dilakukan pembinaan oleh Dinas Kesehatan dan Dinas Pemberdayaan Perempuan Perlindungan Anak Pengendalian Penduduk dan Keluarga Berencanan (DP3AP2KB). Koordinasi dengan Dinas Perumahan Rakyat, Kawasan Permungkiman, dan Pertanahan terkait dengan pembangunan fasilitas yang dapat menunjang kesehatan masyarakat untuk menentukan lokasi pembangunan yang tepat dilakukan sesuai dengan daerah yang mempunyai masalah kesehatan. Koordinasi ini juga tidak terjadwal secara teratur dan bersifat dadakan sesuai kebutuhan program di lapangan dan tidak ada tindak lanjut untuk melakukan koordinasi pada tahap selanjutnya.
Pelaksanaan koordinasi pencegahan stunting di Kota Padang selama ini sesuai dengan kendala yang telah dijelaskan dalam dokumen strategi pencegahan stunting yang telah terbit di tahun 2018. Didalam dokumen tersebut dijelaskan bahwa selama ini implementasi dari wujud pencegahan stunting secara bersama atau terintegrasi memanglah belum dijabarkan kedalam program sektor terkait. Intervensi yang dinilai efektif belum terealisasi sebagaimana mestinya. Meski program pencegahan stunting itu sendiri telah ditetapkan dalam RPJMN 2015-2019 sebagai program nasional yang menginginkan adanya upaya bersama baik antara pemerintah atau pemangku kepentingan maupun masyarakat dalam pencepatan penurunan angka stunting.

\section{Mekanisme Koordinasi Dalam Pelaksanaan Kebijakan Pencegahan Stunting Di Kota Padang}

Berdasarkan dokumen Strategi Nasional Percepatan Stunting (Stranas Stunting) tahun 2018, salah satu strategi pencegahan stunting adalah adanya koordinas di tingkat pusat sampai tingkat daerah. Koordinasi sangat penting dilakukan di tingkat kabupaten/kota untuk upaya percepatan pencegahan stunting. Adanya koordinasi diharapkan dapat melahirkan kebijakan daerah untuk mendukung kebijakan pusat terkait intervensi gizi yang konvergen (TNP2K, 2018:48).

Aturan kegiatan koordinasi di tingkat kabupaten/kota dengan memanfaatakan forum koordinasi yang ada yang dapat mengkoordinir kegiatan intervensi pencegahan stunting terintegrasi di daerah (TNP2K, 2018:52).

Menyikapi ini, Bappenas (2018) mengeluarkan dokumen pedoman pelaksanaan intervensi penurunan stunting terintegrasi di Kabupaten dan Kota dalam upaya pencegahan stunting yaitu melalui penanganan gizi sensitif meliputi ketersediaan air bersih dan sarana sanitasi, keterjangkauan dan kualitas pelayanan gizi dan kesehatan, pemahaman dan praktik 
pengasuhan gizi ibu dan anak, serta pemenuhan pangan bergizi yang lebih baik. Intervensi gizi sensitif umumnya dilaksanakan di luar Kementerian Kesehatan, maka perlu adanya integrasi dalam proses melahirkan program/kegiatan OPD hasil kesepakatan Rembuk Stunting ke dalam RKPD dan Renja OPD.

Namun di Kota Padang belum terealisasi pelaksanaan koordinasi yang fokus membahas tentang pencegahan stunting tersebut. Terlihat dari hasil wawancara dari beberapa dinas di Kota Padang yang menyatakan bahwa stunting adalah programnya Dinas Kesehatan dan tidak ada kaitannya dengan program mereka. Kondisi ini terjadi juga dapat disebabkan karena tidak adanya peraturan pemerintah Kota Padang tentang tindakan pencegahan stunting di Kota Padang, sehingga upaya pencegahan stunting hanya dilaksanakan pada Dinas Kesehatan melalui tim Puskesmas dengan program gizi yang dibawahinya. Hal ini juga akan berhubungan erat dengan pendanaan dalam melakukan kegiatan koordinasi tersebut, sehingga koordinasi tidak bisa dilakukan.

Koordinasi yang membahas masalah stunting baru dilakukan di jajaran Dinas Kesehatan Kota Padang karena terkait dengan pelaksanaan program gizi. Pelaksanaan koordinasi dilakukan dalam bentuk Loka Karya Mini yang dilakukan oleh Dinas Kesehatan dengan mengundang pihak puskesmas, pihak kecamatan dan pihak kelurahan.

Hal ini terungkap dari wawancara yang dilakukan terhadap beberapa pimpinan puskesmas, dan staf program gizi di Puskesmas. Yang menyatakan bahwa selama ini stunting pernah dibahas di Lokmin baik itu Lokmin di tingkat puskesmas maupun Lokmin lintas sektor dalam artian pihak kecamatan maupun kelurahan dan stakeholder setempat yang menjadi realisasi langsung dari kejadian stunting. Namun di Lokmin tersebut seperti yang telah dijelaskan sebelumnya tidak terfokus kepada pencegahan stunting secara langsung karena dilokmin tersebut sesuai dengan temuan penelitain tidak hanya stunting yang dibahas namun juga kondisi status gizi lainnya.

Sesuai dengan temuan penelitian, pembahasan stunting hanyalah sebatas sosialisasi penyampaian data dan kendala yang terjadi dilapangan. Beberapa puskesmas koordinasi tersebut tidaklah berlanjut atau tidak ada tindakan setelah Lokmin itu dibahas. Karena sesuai dengan yang dinyatakan oleh dinas kesehatan bahwa sering terkendala pelaksanaannya disebabkan adanya program lain yang juga penting bagi stakeholder. Sehingga sering tidak terealisasi apa yang telah disepakati. Disatu sisi puskesmas yang ada juga merespon langsung terhadap kejadian stunting, karena stunting didaerah puskesmas tersebut tergolong tinggi yaitu salah satunya puskesmas Andalas dengan angka kejadian stunting ditahun 2019 mencapai $15,6 \%$ atau 563 balita terdampak stunting. Angka ini paling tinggi diantara puskesmas lainnya yang ada di Kota Padang. Oleh karena itu puskemas ini melakukan inisiatif sendiri untuk dapat menurunkan angka kejadian stunting didaerah tersebut. Hal ini seperti yang disampaikan oleh informan dari Puskesmas Andalas menyatakan bahwa belum adanya kebijakan khusus Kota Padang tentang stunting maka mereka hanya melakukan koordinasi program rutin di bawah binaan program gizi. Dengan melibatkan stake holder setempat, maka tim puskesmas ini mencetuskan sebuah inovasi "Ayo ceting" (Ayo Cegah Stunting) untuk memudahkan pendekteksian lebih awal dalam pencegahan stunting.

\section{Faktor Penghambat Dalam Pelaksanaan Koordinasi Kebijakan Pencegahan Stunting di Kota Padang}

Berdasarkan pedoman pelaksanaan intervensi penurunan stunting terintegrasi di Kabupaten dan Kota dalam upaya pencegahan stunting 2018. Dinyatakan bahwa peran pemerintah kabupaten/kota yaitu dalam membuat perencanaan dan anggaran program/ kegiatan untuk 
penanganan prioritas, khususnya di lokasi dengan prevalensi stunting tinggi dan/atau kesenjangan cakupan pelayanan yang tinggi, memperbaiki akses layanan untuk intervensi gizi prioritas dan memastikan bahwa ketercapaian ada kelompok sasaran prioritas dalam mendapatkan dan memanfaatkan bantuan yang disediakan, melakukan koordinasi dengan kecamatan dan pemerintah desa dalam pelaksanaan prioritas, meningkatkan sumber daya, sumber dana, dan update data, serta membuat kebijakan daerah berisikan kampanye publik dan menyampaikan perubahan perilaku berdasarkan acuan dalam strategi yang disusun oleh Kementerian Kesehatan, untuk dalam rangka peningkatan kesadaran dan perubahan perilaku masyarakat dalam pencegahan stunting.

Berdasarkan aturan tersebut telah dijelaskan pentingnya peran pemerintah kota dalam pelaksanaan koordinasi dan menyusun kebijakan daerah terkait dengan pencegahan stunting. Namun untuk Kota Padang belum mempunyai kebijakan tentang pencegahan stunting sehingga adanya anggapan dari dinas non kesehatan bahwa masalah stunting ini adalah masalah Dinas Kesehatan dan diketemukan juga bahwa kebijakan pencegahan stunting yang melibatkan banyak lembaga belum diketahui oleh beberapa lembaga pemerintah di Kota Padang. Belum adanya kebijakan ini menjadi salah satu hambatan dalam pelaksanaan koordinasi antar lintas sektoral di Kota Padang. Adanya peraturan suatu kebijakan penting untuk mendorong keberhasilan suatu program. Terutama terhadap masalah stunting yang telah jelas tertuang didalam RPJMN 2015-2019 sebagai program priotas pembangunan nasional di Indonesia. Namun implementasinya di Kota Padang tidak seperti yang diharapkan bahwa meski kebijakan nasional telah mengatur secara jelas adanya upaya pencegahan stunting belum dijabarkan ke dalam bentuk peraturan pemerintah Kota Padang. Sehingga tidak ada penekanan bagi dinas lain untuk dapat terlibat dalam percepatan pencegahan stunting.

Adanya anggapan pemerintah Kota Padang bahwa angka stunting di Kota Padang tidak tergolong tinggi mengakibatkan tidak adanya peraturan khusus tersebut. Namun pada kenyataannya berpengaruh terhadap angka prevalensi stunting di Kota Padang tiap tahunnya yang fluktuatif sehingga untuk 2021 Kota Padang baru lah masuk ke dalam ranah Lokus stunting mengingat angka kejadian stunting ditahun 2020 meningkat. Berdasarkan temuan penelitian pihak kesehatan menyadari bahwa seharusnya lembaga atau OPD lain ikut membantu dalam percepatan stunting sehingga baru lah 2021 nanti ada kebijakan khusus pemerintah Kota Padang yang mengatur keterlibatan lembaga lintas sektor.

Permasalahan ini sesuai dengan pendapat Makinde dalam Purwanto dan Sulistyastuti (2012:85) yang mengemukakan bahwa terdapat beberapa permasalahan yang terjadi dalam proses pengimplementasian kebijakan yaitu tidak adanya penglibatan kelompok sasaran pada implementasi program, realisasi program tanpa pertimbangan kondisi lingkungan sosial, ekonomi, dan politik, terjadinya penyalahgunaan anggaran, kapasitas petugas yang rendah, koordinasi serta monitoring tidak berjalan, kelangkaan teknologi, tujuan kebijakan tidak jelas, komitmen politik, adanya sentralisasi kewenangan, serta adanya ketergantungan terhadap bantuan negara lain.

Faktor lain yang menjadi hambatan dalam pelaksanaan koordinasi kebijakan pencegahan stunting di Kota Padang adalah faktor tidak adanya anggaran khusus untuk pencegahan stunting. Anggaran ini akan berkaitan dengan aturan pemerintah kota. Jika pemerintah kota mengeluarkan aturan maka akan ada anggaran khusus untuk pencegahan stunting di Kota Padang termasuk anggaran untuk pelaksanaan koordinasi lintas sektoral.

Namun, pada kenyataannya selama ini sesuai dengan temuan hasil penelitian 
bahwa anggaran untuk pencegahan stunting di Kota Padang itu hanya berdasarkan pada anggaran program gizi yang dilakukan tiap tahunnya, belum ada anggaran khusus terhadap upaya pencegahan stunting. Program gizi dilaksanakan oleh setiap puskesmas yang ada di Kota Padang. Berdasarkan temuan dilapangan pelaksanaan program gizi tersebut yang memiliki banyaknya sub-sub kegiatan anggarannyapun merupakan bentuk bagian dari partisipasi masyarakat.

Untuk pencegahan stunting di Kota Padang anggaran tersebut barulah ada ketika Kota Padang telah memasuki Lokus stunting di tahun 2021. Anggaran ini juga berpengaruh terhadap sarana dan prasana dalam pendeteksian lebih awal anak stunting serta sosialisasi yang akan dilakukan disetiap wilayah. Karena berdasarkan hasil temuan, pihak kesehatan mengakui bahwa salah satu kelemahan selama ini juga terdapat pada sarana dan prasarana yang dimiliki seperti alat pengukuran dan penimbangan yang ada diposyandu sangat terbatas.

Faktor lain yang menjadi faktor penghambat pelaksanaan koordinasi kebijakan pencegahan stunting di Kota Padang adalah belum adanya persamaan pemahaman dan tingkat kesadaran semua instansi sehingga beranggapan bahwa stunting adalah masalah kesehatan maka yang bertugas adalah dinas kesehatan. Adanya pemahaman ini maka tidak ada inisiatif dari pihak instansi untuk rembuk bersama membicarakan masalah stunting dan mensinkronkan pelaksanaan program dalam rangka pencegahan stunting di masyarakat.

Hal ini juga terjadi karena belum adanya kebijakan khusus pemerintah Kota Padang itu sendiri. Sehingga sosialisi secara spesifik kepada setiap lembaga untuk dapat membantu secara bersama upaya pencegahan stunting belum juga tersampaikan.

Kesadaran pencegahan stunting secara bersama tidak hanya harus dimiliki oleh setiap lembaga namun juga penting untuk kesadaran masyarakat itu langsung. Karena masyakat itu sendiri yang mengatur pola gizi kehidupannya sehari-hari. Namun pada kenyataannya temuan dilapangan, pihak kesehatan menyatakan bahwa kendala yang mereka alami dalam mengatur pola gizi masyarakat adalah ketidak pedulian masyarakat terhadap pola gizi kehidupannya. Hal ini juga mengakibatkan pihak kesehatan untuk lebih aktif dalam memberikan sosialisasi peningkatan kesadaran gizi dimasyarakat.

\section{PENUTUP}

Berdasarkan hasil temuan penelitian yang telah dilakukan tentang koordinasi dalam implementasi kebijakan pencegahan stunting di Kota Padang dapat ditarik beberapa kesimpulan yaitu pelaksanaan koordinasi kebijakan pencegahan stunting di Kota Padang baru berjalan di tingkat sektoral Dinas Kesehatan beserta jajarannya dan belum ada koordinasi antar lintas sektoral dengan instansi lain yang membahas khusus tentang pencegahan stunting, sedangkan mekanisme koordinasi dalam pelaksanaan kebijakan pencegahan stunting di Kota Padang baru dilaksanakan di jajaran Dinas Kesehatan berupa lokakarya mini dengan melibatkan tim puskesmas, petugas kecamatan dan tenaga kelurahan melalui program gizi, sementara itu faktor penghambat dalam pelaksanaan koordinasi kebijakan pencegahan stunting di Kota Padang adalah karena belum adanya regulasi mempengaruhi kejelasan fungsi dan tugas pokok dari lembaga yang terlibat, tidak adanya anggaran khusus tentang pencegahan stunting serta belum adanya kesadaran saling membantu dalam percepatan pencegahan stunting secara bersama. Hal ini disebabkan karena anggapan rendahnya kejadian stunting di Kota Padang dan Kota Padang tidak termasuk ke dalam daerah lokus stunting. 
Febby Febrian, Rahmadani Yusran I Koordinasi dalam Implementasi Kebijakan Pencegahan Stunting di Kota Padang

\section{DAFTAR KEPUSTAKAAN}

Akmal. 2006. Koordinasi Antar Instansi Terkait Dalam Pelaksanaan Pembangunan di Daerah. Jurnal Demokrasi. Vol 5. No 1. Hal 1-12. Diakses dari link : http://ejournal.unp. ac.id/index.php/jd/article/download/10 66/898 (12 Mei 2020).

Doddy Izwardi. 2019. Kebijakan dan Strategi Penanggulangan Stunting di Indonesia. Kementerian Kesehatan Republik Indonesia. Diakses dari Link: https://persi.or.id/images/2019/data/FI NAL_PAPARAN_PERSI_22_FEB_2 019_Ir._Doddy.pdf (09 Mei 2020).

Hasibuan, Melayu S.P. 2014. Manajemen (Dasar, Pengertian, dan Masalah). Jakarta: PT Bumi Aksara.

Harian Haluan. 2018. Dinkes Padang Catat 3.269 Anak Kerdil, Balita Stunting PR Bersama. Diakses dari link : https://har ianhaluan.com/news/detail/72165/dink es-padang-catat-3269-anak-kerdilbalita-stunting-pr-bersama

Februari 2020, 20.09 WIB).

Islamy, Irfan. 2009. Prinsip-Prinsip Perumusan Kebijaksanaan Negara. Jakarta: Bumi Aksara.

Kementerian PPN/Bappenas.

2018.

Pedoman Pelaksanaan Intervensi Penurunan Stunting Terintegrasi di Ka bupaten/Kota. Diakses dari link : http:/ /tnp2k.go.id/filemanager/files/Rakorni s\%202018/Pedoman\%20Pelaksanaan $\% 20$ Intervensi\%20Penurunan\%20Stun ting\%20Terintegrasi\%20Di\%20Kabup aten\%20Kota.pdf (15 Mei 2020) .

Kementerian Keuangan dan Kementerian PPN/Bappenas. 2019. Laporan Pemantauan Kinerja Anggaran dan Pembangunan Program Percepatan Pencegahan dan Penurunan Stunting $\mathrm{S}$ emester 1.
Diakses dari link : http://anggaran.kem enkeu.go.id/content/Publikasi/Laporan $\%$ 20Semester\%20Program\%20Percep atan\%20Pencegahan\%20Stunting\%20 2019.pdf (22 Februari 2020).

Keputusan Menteri Kesehatan Republik In donesia No. 1995/MENKES/SK/XII/2 010 tentang Standar Antropometri Pen ilaian Gizi Anak. Diakses dari lin: https://drive.google.com/file/d/0B_8e7 6vgfxWLcFo1cHB0cUNUYTQ/view (20 Mei 2020).

Mulyadi, Deddy. 2016. Studi Kebijakan Publik dan Pelayanan Publik. Bandung : Alfabeta.

Ndaraha, Taliziduhu. 2003. KYBERNOLO GY (Ilmu Pemerintahan Baru) 1. Jakarta: Rineka Cipta.

Purwanto, E.A \& Suliyastuti, D.R. (2012). Implementasi Kebijakan Publik (Konsep dan Aplikasinya di Indonesia). Yogyakarta: Gava Media.

Peraturan Presiden No. 42 tahun 2013 tentang Gerakan Nasional Percepatan Perbaikan Gizi.

Republika. 2020. BKKBN Penanggung Jawab Utama Penanggulangan Stunting. Diakses dari link: https://republika.co.id/berita/qhffx 738 0/bkkbn-penanggung-jawab-utamapenanggulangan-stunting (23 Oktober 2020, 19.18 WIB).

Rini Archda Saputri dan Jeki Tumangger. 2019. Hulu Hilir Penanggulangan Stunting di Indonesia. Journal of Political Issues. Vol 1. No 1. Hal 11-9. Diakses dari link : https://media.neliti.com/media/publica tions/286747-hulu-hilirpenanggulangan-stunting-di-inbeb0ec40.pdf (07 Mei 2020).

Sugiyono. 2012. Memahami Penelitian 
Febby Febrian, Rahmadani Yusran| Koordinasi dalam Implementasi Kebijakan Pencegahan Stunting di Kota Padang

Kualitatif. Bandung: Alfabeta.

Taufiqurokhman. 2014. Kebijakan Publik (Pendelegasian Tanggung Jawab Negara Kepada Presiden Selaku Penyelenggara Pemerintahan). Jakarta: Fakultas Ilmu Sosial dan Ilmu Politik Universitas Moestopo Beragama (Pers).

Tim Nasional Percepatan Penanggulangan Kemiskinan. 2018. Strategi Nasional Percepatan Pencegahan Stunting Periode 2018 - 2024. Diakses dari link :

http://tnp2k.go.id/filemanager/files/Ra kornis\%202018/Stranas\%20Percepata $\mathrm{n} \% 20$ Pencegahan\%20Anak\%20Kerdil .pdf (15 Februari 2020).
Undang-Undang No. 36 tahun 2009 tentang Kesehatan.

Undang-Undang No. 18 tahun 2012 tentang Pangan.

WHO. Diakses dari link : https://who.int/n utrition/healthygrowthproj_stunted_vi deos/en/ (09 Mei 2020).

Y Aprina, R Yusran. 2019. Implementasi Peraturan Daerah Kota Bukittinggi Nomor 2 Tahun 2015 Tentang Pencegahan Dan Penanggulangan Bahaya Kebakaran. Jurnal Mahasiswa Ilmu Administrasi Publik, 2019. diakses dari link: http://jmiap.ppj.unp.ac.id/index.php/j miap/article/view/49 